\title{
The influence of the intestinal microflora on disaccharidase activities in the chick
}

\author{
By R. C. SIDDONS* AND MARIE E. COATES \\ National Institute for Research in Dairying, Shinfield, Reading $R G 2{ }_{9} A T$

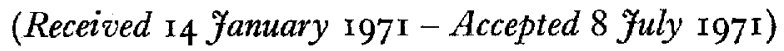

\begin{abstract}
I. Maltase sucrase, palatinase (the enzyme that hydrolyses palatinose, i.e. 6-0- $\alpha$-D-glucopyranosyl-D-fructose) and lactase activities were measured in the small and large intestines of germ-free and conventional chicks given either a diet of purified ingredients or a practical chick mash.

2. With the purified diet there were no differences in body-weight or small intestinal disaccharidase activities between germ-free and conventional chicks. With the chick mash the germ-free birds were heavier and had higher total amounts of maltase, sucrase and palatinase activities in the small intestine than did their conventional controls. When disaccharidase activities were expressed in terms of body-weight there were no differences between birds in the two environments. Enzyme activities were consistently higher in the birds given chick mash.

3. Inclusion of milled fibre in the purified diet did not increase the weight or disaccharidase activities of the small intestine in either environment.

4. Lactase was virtually absent from the small intestine of birds in both environments and from the large intestine of germ-free birds. There was appreciable lactase activity in the large intestinal contents of conventional chicks, and it was increased by inclusion of lactose in the diet.

5. When lactose was the sole source of carbohydrate the birds grew poorly but mortality rate was less among conventional compared with germ-free chicks.

6. It was concluded that the presence of micro-organisms has no direct effect on disaccharidase production in the small intestine of the chick. Microbial lactase is present in the large intestine, and at least some of the products of its action can be utilized by the bird.
\end{abstract}

In a study of the characteristics and distribution of the disaccharidases in the intestinal tract of the chick Siddons ( 1969 ) showed that, apart from the absence of trehalase, the pattern of activity resembled that of the weaned rat. Investigations with gnotobiotic rats indicated that the conventional microflora of the intestine could influence the amounts of intestinal disaccharidase activity (Reddy \& Wostmann, r966; Reddy, Pleasants \& Wostmann, I968). The experiments reported here were undertaken to determine whether, and to what extent, this was also true for the chick. The enzymes studied were maltase, sucrase, palatinase (the enzyme that hydrolyses palatinose, i.e. 6-o- $\alpha$-D-glucopyranosyl-D-fructose) and lactase. Palatinose and isomaltose are hydrolysed by the same enzyme in the chick small intestine (Siddons, I970).

* Present address: The Wellcome Trust Research Laboratories, PO Box 3640, Nairobi, Kenya. 


\section{MATERIALS AND METHODS}

Chicks. Eggs produced by Light Sussex hens mated with Rhode Island Red cocks were incubated in a standard commercial incubator for $18 \mathrm{~d}$ and then decontaminated with peracetic acid as described by Harrison ( 1969 ). Those required for the production of germ-free chicks were passed into sterilized stainless-steel Gustafsson isolators and left for a further $3 \mathrm{~d}$ to hatch; the remainder were returned to the incubator and the chicks subsequently hatched were used as conventional controls. On the day of hatching the germ-free birds were distributed in groups of four or five in wire-mesh cages inside the isolators; the conventional controls were housed in similar cages in

\section{Table I. Composition of diets}

\section{Chick mash}

Ground maize
Ground wheat
Middlings
White fish meal
Dried skim milk
Dried grass meal
Dried brewers' yeast
Limestone flour
Salt mixturef
Maize oil

Purified diet

$\begin{array}{lc}\text { Maize starch } & 59.65 \\ \text { Casein } & 18.0 \\ \text { Gelatin } & 10.0 \\ \text { Salt mixture* } & 6.0 \\ \text { L-Cystine } & 0.3 \\ \text { Choline chloride } & 0.15 \\ \text { Inositol } & 0.10 \\ \text { Vitamin triturate } & 0.80 \\ \text { Maize oil } & 5.0\end{array}$

I700 i.u. retinyl acetate and $\mathrm{r} 60$ i.u. cholecalciferol were added to each $100 \mathrm{~g}$ of the chick mash.

* Provided, per I00 g diet: $\mathrm{CaCO}_{3}$ I.7I g; $\mathrm{CaHPO}_{4} .2 \mathrm{H}_{2} \mathrm{O}$ I.7I g; $\mathrm{KH}_{2} \mathrm{PO}_{4} \mathrm{I} \cdot 33 \mathrm{~g} ; \mathrm{NaCl} 867 \mathrm{mg}$; $\mathrm{MgSO}_{4} \cdot \mathrm{H}_{2} \mathrm{O} 267 \mathrm{mg} ; \mathrm{FeSO}_{4} \cdot{ }_{5} \mathrm{H}_{2} \mathrm{O} 67 \mathrm{mg} ; \mathrm{MnSO}_{4} \cdot 4 \mathrm{H}_{2} \mathrm{O} 27 \mathrm{mg} ; \mathrm{ZnSO}_{4} \cdot{ }_{7} \mathrm{H}_{2} \mathrm{O}$ I3 mg; KI $3.7 \mathrm{mg}$; $\mathrm{CuSO}_{4} \cdot 5 \mathrm{H}_{2} \mathrm{O}+6 \mathrm{mg}$.

$\uparrow$ Provided, per $100 \mathrm{~g}$ diet: biotin $80 \mu \mathrm{g}$; folic acid $600 \mu \mathrm{g}$; thiamin $1.2 \mathrm{mg}$; pyridoxine $\mathrm{I} \cdot 6 \mathrm{mg}$; riboflavin $2.4 \mathrm{mg}$; calcium pantothenate $6.0 \mu \mathrm{g}$; nicotinic acid $\mathrm{r} 6 \mathrm{mg}$; cyanocobalamin $8 \mu \mathrm{g}$; retinyl acetate 6800 i.u.; cholecalciferol 640 i.u.; menaphthone $2 \mathrm{mg}$; $\alpha$-tocopheryl acetate $4 \mathrm{mg}$.

f $\mathrm{MnSO}_{4} \cdot 4 \mathrm{H}_{2} \mathrm{O}$ 13.6 $\mathrm{g}$, $\mathrm{KI} 0^{\circ} 136 \mathrm{~g}, \mathrm{NaCl}_{213} \cdot 3 \mathrm{~g}$.

a room where the environmental conditions could be varied to match those within the isolators. Males and females were distributed evenly throughout the experimental groups. At intervals during the experiments sterility checks were made on the germfree birds as described by Fuller (1968).

Diets. Two types of diet were used. One was a practical chick mash in which the carbohydrate was supplied mainly from milled cereal grains (maize and wheat). The other was composed of purified ingredients, with maize starch as the source of carbohydrate. Their compositions are given in Table r. On some occasions the maize starch was totally replaced by lactose or glucose, and in an experiment to determine the effect of fibre on enzyme activities the purified diet was modified by inclusion of $20 \%$ powdered wheat straw at the expense of an equal quantity of the carbohydrate. The diets both for germ-free and conventional chicks were sterilized by $\gamma$-radiation at $5 \mathrm{Mrd}$. The vitamin content was increased above the usual levels to allow for possible losses during sterilization.

Experimental procedure. The birds were usually maintained on the diets from the day of hatching until about the 24th day of age. The experiment with a lactose diet was terminated after $\mathbf{1} 4 \mathrm{~d}$ because the birds grew poorly and deaths were frequent. In all 
but the first experiment the chicks were fasted for $16 \mathrm{~h}$ before the intestines were removed for analysis. When it was necessary to obtain measurements on the intestinal wall and contents separately, the contents were washed out of the anaesthetized birds as described by Siddons (1969). On the the other occasions the birds were killed by fracture of the neck, and determinations were made on homogenates of the combined wall and contents. The small intestine was that portion of the alimentary tract between the gizzard and the ileo-caecal junction; the large intestine consisted of the two caecums and the colon.

Enzyme determinations. Determinations of maltase, sucrase, palatinase and lactase activities were made as described by Siddons ( 1969 ). Results are expressed as total units of activity per small or large intestine.

Plan of experiments. All investigations were made on comparable groups of germfree and conventional chicks from the same batch of eggs. Previous experience had shown that measurement of enzymic activity was simplified if the birds were fasted for $16 \mathrm{~h}$ before they were killed. After this period the small intestine was empty and complications in the assay, due to the presence of endogenous carbohydrate in the contents, were not encountered. However, it was considered necessary to check that the period of fasting did not obscure any difference between germ-free and conventional chicks. Expt I was therefore an exploratory test, with groups of five birds given the purified diet, to determine the effect of fasting on the amounts and distribution of disaccharidase activities in the two environments. Thereafter a $16 \mathrm{~h}$ fasting period was imposed before samples were taken.

Expt 2, with fifteen birds per treatment, was an investigation of the disaccharidase levels in birds given the chick mash. Since some of the results were at variance with those of Expt $x$, Expt 3 was a direct comparison between groups of eight chicks given either the purified diet or the mash.

The influence of individual components of the diet was then examined. In Expt 4, again with eight birds per treatment, the effects of including fibre in the purified diet with starch or glucose as the carbohydrate source were investigated. In Expt 5 the disaccharidase levels were compared in groups of fifteen chicks given the purified diet in which carbohydrate was supplied either as lactose or as starch.

Statistical treatment. Analysis of variance was carried out on values for individual birds except in Expt 4, when cage means of four birds were used. Individual treatment means, main effects and interactions are given in Tables 2, 4, 5 and 6. For brevity and consistency, main effects are given even when there was a significant interaction. In such cases the individual treatment means have been compared.

\section{RESULTS}

\section{Expt I. Effect of fasting}

The disaccharidase activities in the wall and contents of the large and small intestines of groups of five germ-free and conventional chicks that had either been fasted for $\mathrm{I} 6 \mathrm{~h}$ or allowed continuous access to the purified diet are given in Table 2 .

In all four groups the lactase activity of the small intestine was very low and was 
confined to the wall. The bulk of activity of the other three enzymes also was in the wall. The reverse was true in the large intestine where the greater proportion of activity was in the contents.

Table 2. Disaccharidase activities in the small and large intestines of germ-free and conventional chicks on a purified diet, fed continuously or fasted for $16 \mathrm{~h}$

(Five birds in each group)

\begin{tabular}{|c|c|c|c|c|c|c|c|c|}
\hline \multirow[b]{2}{*}{ Body-wt } & \multicolumn{2}{|c|}{ Germ-free } & \multicolumn{2}{|c|}{ Conventional } & \multirow{2}{*}{$\begin{array}{l}\text { SE of a } \\
\text { group } \\
\text { mean } \\
(16 \mathrm{df})\end{array}$} & \multirow{2}{*}{$\begin{array}{c}\text { Effect of } \\
\text { feeding } \\
\frac{1}{2}\{(B+D) \\
-(A+C)\}\end{array}$} & \multirow{2}{*}{$\begin{array}{c}\text { Effect of } \\
\text { environment } \\
\frac{1}{2}\{A+B) \\
-(C+D)\}\end{array}$} & \multirow{2}{*}{$\begin{array}{c}\text { Interac- } \\
\quad \text { tion } \\
\frac{1}{2}\{(B-A) \\
-(D-C)\}\end{array}$} \\
\hline & $\begin{array}{c}\text { Fasted } \\
(A)\end{array}$ & $\begin{array}{c}\text { Fed } \\
(B)\end{array}$ & $\begin{array}{l}\text { Fasted } \\
(C)\end{array}$ & $\begin{array}{l}\text { Fed } \\
(D)\end{array}$ & & & & \\
\hline (g)... & 268 & 271 & 237 & 298 & 20.4 & 32 & 2 & -29 \\
\hline
\end{tabular}

Enzyme activity (total units) in segments of small intestine

\begin{tabular}{|c|c|c|c|c|c|c|c|c|}
\hline Maltase & & & & & & & & \\
\hline Contents & 416 & 624 & $46 r$ & 666 & $85 \cdot 4$ & $206 *$ & -44 & -2 \\
\hline Wall & 15120 & I 8748 & 14164 & 19640 & $2773 \cdot 6$ & $455^{2}$ & 32 & 924 \\
\hline Total & I 5536 & 19372 & 14625 & 20306 & $2841 \cdot 7$ & 4758 & -12 & -922 \\
\hline Sucrase & & & & & & & & \\
\hline Contents & & 60 & 82 & 80 & $27 \cdot 8$ & -6 & $-\mathrm{I} 6$ & -4 \\
\hline Wall & 2640 & 3556 & 2770 & 4104 & $430 \cdot 3$ & I $125^{*}$ & -339 & -209 \\
\hline Total & 2710 & $36 r 6$ & 2852 & 4184 & $440 \cdot 8$ & $\operatorname{III} 9^{*}$ & -355 & -213 \\
\hline Palatinase & & & & & & & & \\
\hline Contents & I6 & 10 & 20 & 19 & $3 \cdot 8$ & -4 & -7 & -2 \\
\hline Wall & 816 & 1109 & 859 & 1272 & I $14 \cdot 8$ & $353^{* *}$ & -103 & -60 \\
\hline Total & 832 & I I I 9 & 879 & 1291 & I $16 \cdot 1$ & $349^{* *}$ & - IIO & -62 \\
\hline Lactase & & & & & & & & \\
\hline Contents & & & & Not & tectable & & & \\
\hline Wall & 40 & 64 & 45 & $8 I$ & $5 \cdot 7$ & $30 * * *$ & - I I & -6 \\
\hline Total & & & & Sar & as wall & & & \\
\hline
\end{tabular}

\begin{tabular}{|c|c|c|c|c|c|c|c|c|}
\hline \multicolumn{9}{|c|}{ its of large intestine } \\
\hline Contents & 2449 & I 342 & I 6,38 & 729 & $24 I \cdot 6$ & - I $008 * * *$ & $7 \times 2^{* *}$ & -99 \\
\hline Wall & I 199 & 1408 & $44 \mathrm{I}$ & 652 & I 34.5 & 210 & $757^{* * *}$ & $-\mathbf{I}$ \\
\hline Total & 3648 & 2750 & 2079 & I 38 I & $283 \cdot 4$ & $-798^{*}$ & I $469^{* * * *}$ & -100 \\
\hline \multicolumn{9}{|l|}{ Sucrase } \\
\hline Contents & $3^{14}$ & 220 & 3 Io & I68 & $49 \cdot 4$ & - I I 8* & 28 & 24 \\
\hline Wall & I33 & I 43 & 64 & 90 & I I. I & I8 & $6 \mathrm{r}^{* * * *}$ & -8 \\
\hline Total & 448 & 363 & 374 & 258 & $52 \cdot 4$ & -IOI & 89 & I 6 \\
\hline \multicolumn{9}{|l|}{ Palatinase } \\
\hline Contents & 72 & 38 & 86 & 45 & I3:3 & $-38^{*}$ & - II & 4 \\
\hline Wall & 20 & 25 & IO & I I & $3 \cdot 1$ & 3 & $12 * *$ & 2 \\
\hline Total & 92 & 62 & 96 & 56 & 13.4 & $-35^{*}$ & $\mathbf{I}$ & 5 \\
\hline \multicolumn{9}{|l|}{ Lactase } \\
\hline Contents & $\circ$ & 0 & $\mathbf{x} 45$ & 68 & $19.3(a)$ & $-3^{8}$ & $-106 * * *$ & $3^{8}$ \\
\hline Wall & I I & 9 & ro & IO & $I \cdot 6$ & $-\mathrm{I}$ & o & $-I$ \\
\hline Total & I I & 9 & I 55 & 78 & $19 \cdot 9(b)$ & -40 & $-106 * * *$ & 38 \\
\hline
\end{tabular}

(a), (b) For lactase contents $(a)$ and total (b) the SE of group means are heterogeneous. The SE of each conventional group is for $(a) 27 \cdot 3$ and for $(b) 28 \cdot 0(8 \mathrm{df})$; the SE of each germ-free group is for $(a) 0.0$ and for $(b)$ I.8 ( $8 \mathrm{df}$ ). The values of 19.3 and 19.9 quoted in the table are pooled values applicable to main effects and the interaction. SE of a main effect or of the interaction equals SE of a group mean.

Levels of significance: * $P<0.05,{ }^{* *} P<0.01, * * * P<0.001$. 
There were several instances of significant differences between fasted and fed birds but none were apparent between activities in the small intestine of germ-free and conventional birds. In the large intestine the most notable environmental difference was the absence of lactase from the contents of germ-free chicks.

\section{Expts 2 and 3. Effect of diet}

A comparison between the total disaccharidase activities in the small and large intestines of groups of fifteen chicks given the practical chick mash gave the results shown in Table 3. The germ-free chicks attained a higher body-weight than that of their conventional controls. Again lactase was practically absent from the large

\section{Table 3. Intestinal disaccharidase activities in germ-free and} conventional chicks given a practical chick mash

\begin{tabular}{|c|c|c|c|c|}
\hline \multicolumn{5}{|c|}{ (Means for fifteen birds) } \\
\hline & $\begin{array}{c}\text { Germ-free } \\
\quad(A)\end{array}$ & $\begin{array}{c}\text { Conventional } \\
(B)\end{array}$ & $\begin{array}{l}\text { SE of a } \\
\text { group mean } \\
(28 \mathrm{df})\end{array}$ & $\begin{array}{c}\text { Difference } \\
(A)-(B)\end{array}$ \\
\hline Body-wt (g)... & & 186 & $17 \cdot 1$ & $42^{* * *}$ \\
\hline \multicolumn{5}{|c|}{ Total activity (units) in small intestine } \\
\hline Maltase & 16337 & 10592 & $753^{\prime 4}$ & $5745^{* * *}$ \\
\hline Sucrase & 3112 & 1605 & 149.8 & I $507 * * *$ \\
\hline Palatinase & 755 & 480 & $37 \cdot 9$ & $275^{* * *}$ \\
\hline Lactase & 44 & 53 & $3 \cdot 2$ & -8 \\
\hline \multicolumn{5}{|c|}{ Total activity (units) in large intestine } \\
\hline Maltase & 3967 & 2834 & $394: 3$ & I I 33 \\
\hline Sucrase & 677 & 609 & $80 \cdot 2$ & 68 \\
\hline Palatinase & $\mathrm{x} 47$ & 200 & $16 \cdot 9$ & $-53^{*}$ \\
\hline Lactase & 7 & 227 & $28 \cdot 2(a)$ & $-220 * * *$ \\
\hline
\end{tabular}

(a) For lactase activity in the large intestine the SE of group means are heterogeneous. The SE of the conventional group is $1 \cdot 0\left(I_{4} \mathrm{df}\right)$ and the SE of the germ-free group is $\mathrm{I}^{\circ} \mathrm{O}\left(\mathrm{I}_{4} \mathrm{df}\right)$. The value of $28 \cdot 2$ quoted in the table is a pooled value.

Levels of significance: $* P<0.05, * * P<0.001$.

intestine of germ-free birds but, unlike the results from the previous experiment with the purified diet, on this occasion the small intestines of germ-free birds contained significantly higher amounts of maltase, sucrase and palatinase. A direct comparison was therefore made between groups of eight germ-free and conventional chicks given either the purified diet or the practical mash. The results are given in Table 4 , from which it can be seen that on the mash the germ-free chicks achieved a higher bodyweight and had greater amounts of maltase, sucrase and palatinase activities in the small intestine than their conventional counterparts, whereas germ-free and conventional chicks given the purified diet attained similar body-weights and had similar levels of disaccharidase activity in the small intestine. Once more, lactase was absent from the germ-free large intestines. On the assumption that the smaller birds would have a proportionately smaller intestinal area the results were recalculated per $100 \mathrm{~g}$ body-weight. In consequence, the differences between values for the germ-free and 
conventional chicks virtually disappeared. This effect is illustrated in Fig. I. Whichever method was used to express the results, values were consistently higher in birds given the mash.

\section{Table 4. Intestinal disaccharidase activities in germ-free and conventional chicks given either a purified diet or a practical chick mash}

(Means for eight birds)

\begin{tabular}{|c|c|c|c|c|c|c|c|c|}
\hline \multirow[b]{2}{*}{$\begin{array}{c}\text { Body-wt } \\
(\mathrm{g}) \quad \ldots\end{array}$} & \multicolumn{2}{|c|}{ Germ-free } & \multicolumn{2}{|c|}{ Conventional } & \multirow[b]{2}{*}{$\begin{array}{c}\text { SE of a } \\
\text { group } \\
\text { mean } \\
(28 \mathrm{df}) \\
\text { I6.6 }\end{array}$} & \multirow{2}{*}{$\begin{array}{c}\text { Effect } \\
\text { of } \\
\text { feeding } \\
\frac{1}{2}\{(A+C) \\
-(B+D)\} \\
72^{* * *}\end{array}$} & \multirow{2}{*}{$\begin{array}{c}\text { Effect } \\
\text { of } \\
\text { environment } \\
\frac{1}{2}\{(A+B) \\
-(C+D)\} \\
3^{6 *}\end{array}$} & \multirow[b]{2}{*}{$\begin{array}{c}\text { Interaction } \\
\frac{1}{2}\{(A-B) \\
-(C-D)\} \\
-34^{*}\end{array}$} \\
\hline & $\begin{array}{l}\text { Purified } \\
\text { diet } \\
(A) \\
\text { 3I I }\end{array}$ & $\begin{array}{l}\text { Mash } \\
(B) \\
274\end{array}$ & $\begin{array}{l}\text { Purified } \\
\text { diet } \\
(C) \\
309\end{array}$ & $\begin{array}{l}\text { Mash } \\
(D) \\
203\end{array}$ & & & & \\
\hline \multicolumn{9}{|c|}{ Total activity (units) in small intestine } \\
\hline $\begin{array}{l}\text { Maltase } \\
\text { Sucrase } \\
\text { Palatinase } \\
\text { Lactase }\end{array}$ & $\begin{array}{r}13894 \\
2712 \\
576 \\
34\end{array}$ & $\begin{array}{r}22904 \\
4281 \\
913 \\
45\end{array}$ & $\begin{array}{r}14995 \\
3285 \\
703 \\
48\end{array}$ & $\begin{array}{r}17942 \\
3423 \\
744 \\
44\end{array}$ & $\begin{array}{r}524.7 \\
265.0 \\
52.5 \\
3.3\end{array}$ & $\begin{array}{c}-5978 * * * \\
-854^{* *} \\
-189^{* *} \\
-4\end{array}$ & $\begin{array}{r}193^{\circ} \\
142 \\
21 \\
-6\end{array}$ & $\begin{array}{c}-3032 \\
-716^{*} \\
-418^{*} \\
8^{*}\end{array}$ \\
\hline \multicolumn{9}{|c|}{ Total activity (units) in large intestine } \\
\hline $\begin{array}{l}\text { Maltase } \\
\text { Sucrase } \\
\text { Palatinase } \\
\text { Lactase }\end{array}$ & $\begin{array}{r}3334 \\
686 \\
172 \\
1\end{array}$ & $\begin{array}{r}3930 \\
739 \\
165 \\
1\end{array}$ & $\begin{array}{r}3620 \\
1009 \\
241 \\
63\end{array}$ & $\begin{array}{r}3632 \\
1188 \\
292 \\
328\end{array}$ & $\begin{array}{l}494 \cdot 2 \\
182.6 \\
37 \cdot 9 \\
50.9(a)\end{array}$ & $\begin{array}{c}-304 \\
-116 \\
-22 \\
-132 *\end{array}$ & $\begin{array}{c}6 \\
-386 * \\
-98 * \\
194\end{array}$ & $\begin{array}{r}-292 \\
63 \\
29 \\
I_{32}^{*}\end{array}$ \\
\hline
\end{tabular}

(a) For lactase the $\mathrm{sE}$ of group means are heterogeneous. The SE of each conventional group is $\pm 72.0\left(I_{4} \mathrm{df}\right)$ and the $\mathrm{sE}$ of each germ-free group is \pm 0.5 ( $\left.14 \mathrm{df}\right)$. The value of 50.9 quoted in the table is a pooled value applicable to main effects and the interaction.

SE of a main effect or of the interaction equals SE of a group mean.

Levels of significance: * $P<0.05$, * $P<0.01$, *** $P<0.00 x$.

\section{Expt 4. Effect of dietary fibre}

One of the major differences between the two diets used in Expt 3 was in their bulk. The chick mash contained a considerable amount of fibre contributed by the cereals, whereas the purified diet contained none. An investigation was therefore made of the effects of replacing some of the carbohydrate in the purified diet by fibre in the form of milled wheat straw. The diet with maize starch and, in addition, a similar diet in which the maize starch had been replaced by glucose, were given to groups of eight germ-free or conventional chicks with and without $29 \%$ wheat straw. The effects on body-weight, intestine weight and disaccharidase activities are recorded in Table 5 .

Apart from the groups given the starch diet with wheat straw, the conventional birds were slightly but not significantly heavier than their germ-free counterparts. The weight of the small intestine was always lower in the germ-free chicks. On the whole, in either environment the enzyme activities were lower in the birds given fibre. When calculated in terms of body-weight, between-treatment differences were reduced, although the tendency towards lower values on the diets with fibre was still apparent. In the large intestine the highest mean value for all four enzymes was found in the conventional birds given starch, and the birds given glucose had lower values in both environments. 
Activity (total units) small intestine)
Acrivity (units; $100 \mathrm{~g}$ body-weight)

Maltase
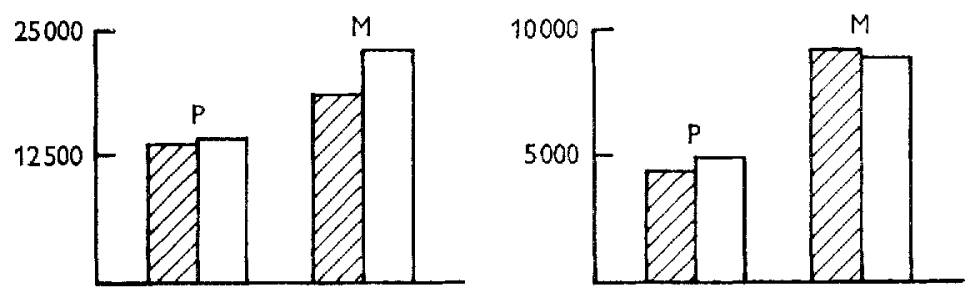

Sucrase
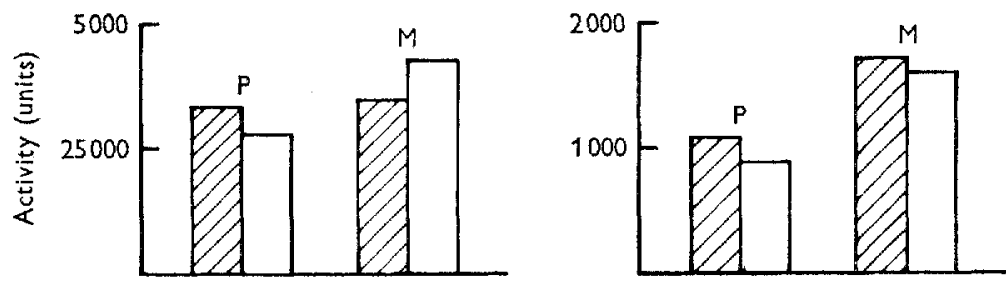

Palatinase
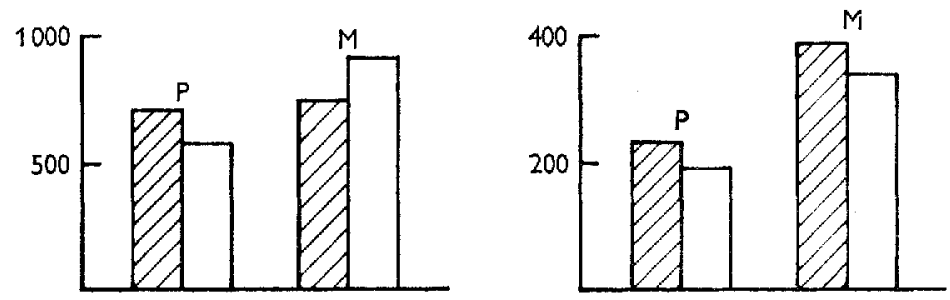

Fig. I. Disaccharidase activities in the small intestine of germ-free ( $\square$ ) and conventional $(\square)$ chicks given a purified diet (P) or a chick mash (M). The results are means for eight birds calculated as total units/small intestine or as units/roo $\mathrm{g}$ body-weight.

\section{Expt 5. Effect of dietary lactose}

To determine whether or not lactase activity was influenced by dietary lactose, groups of fifteen germ-free and conventional chicks were given either the purified diet or a similar one in which lactose replaced the starch. There was a high mortality rate among the germ-free birds given lactose; only seven remained alive on the $1_{4}$ th day and the experiment was ended then. Results of disaccharidase determinations are given in Table 6.

The chicks given the starch diet grew significantly better than those given lactose. In the small intestine the maltase, sucrase and palatinase activities were, on the whole, highest in the germ-free birds given lactose and lowest in the conventional birds 


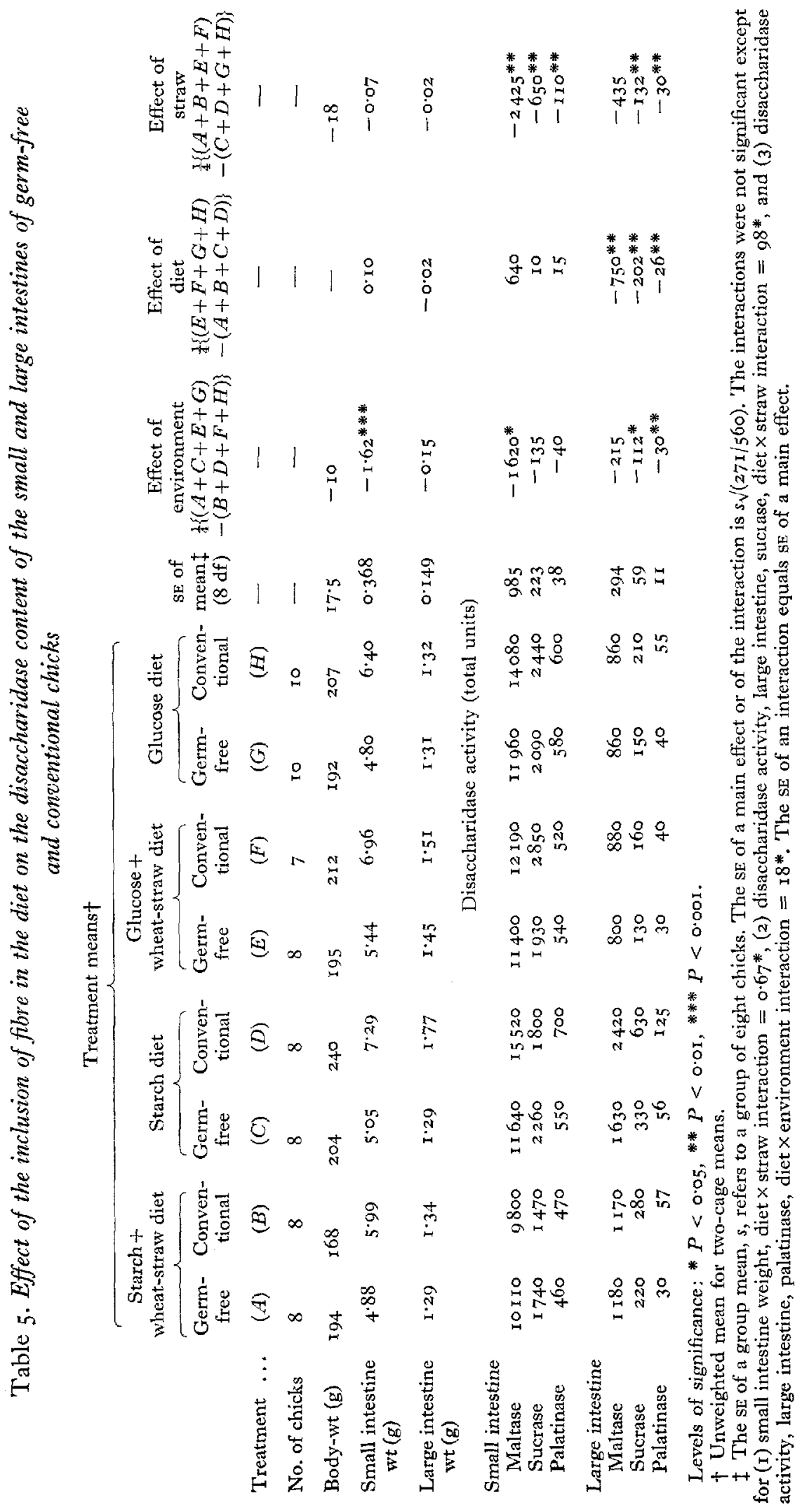


given starch. In the large intestine the reverse effect was generally noted. In both sites, but particularly in the large intestine, the conventional lactose-fed birds had significantly higher levels of lactase than their germ-free counterparts.

Table 6. Effect of dietary lactose on intestinal disaccharidase activities in germ-free and conventional chicks

\begin{tabular}{|c|c|c|c|c|c|c|c|c|}
\hline & \multicolumn{2}{|c|}{ Germ-free } & \multicolumn{2}{|c|}{ Conventional } & \multirow[b]{2}{*}{$\begin{array}{l}\text { SE of a } \\
\text { group } \\
\text { meant } \\
\left(4^{8} \mathrm{df}\right)\end{array}$} & \multirow[b]{2}{*}{$\begin{array}{c}\text { Effect } \\
\text { of diet } \\
\frac{1}{2}\{(A+C) \\
-(B+D)\}\end{array}$} & \multirow[b]{2}{*}{$\begin{array}{c}\text { Effect of } \\
\text { environment } \\
\frac{1}{2}\{(A+B) \\
-(C+D)\}\end{array}$} & \multirow[b]{2}{*}{$\begin{array}{c}\text { Interaction } \\
\frac{1}{2}\{(A+B) \\
-(C-D)\}\end{array}$} \\
\hline & $\begin{array}{c}\text { Lactose } \\
\text { diet } \\
(A)\end{array}$ & $\begin{array}{c}\text { Starch } \\
\text { diet } \\
(B)\end{array}$ & $\begin{array}{l}\text { Lactose } \\
\text { diet } \\
\text { (C) }\end{array}$ & $\begin{array}{l}\text { Starch } \\
\text { diet } \\
(D)\end{array}$ & & & & \\
\hline $\begin{array}{l}\text { No. of birds } \\
\text { surviving to } \\
\text { I4 d ... }\end{array}$ & 7 & I5 & 15 & 15 & $-\cdots$ & - & 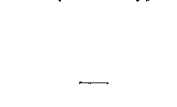 & 一 \\
\hline $\begin{array}{l}\text { Body-wt } \\
\qquad \text { (g) } \quad \ldots\end{array}$ & $9 \mathbf{I}$ & 123 & 100 & I I I & 3.5 & $-2 \mathrm{I} * * *$ & $\mathbf{I}$ & $-10^{*}$ \\
\hline \multicolumn{9}{|c|}{ Total activity (units) in small intestine } \\
\hline $\begin{array}{l}\text { Maltase } \\
\text { Sucrase } \\
\text { Palatinase } \\
\text { Lactase }\end{array}$ & $\begin{array}{r}10690 \\
2279 \\
414 \\
30\end{array}$ & $\begin{array}{r}6726 \\
1415 \\
363 \\
28\end{array}$ & $\begin{array}{r}6770 \\
\times 300 \\
301 \\
38\end{array}$ & $\begin{array}{r}5370 \\
\mathrm{I} 163 \\
305 \\
23\end{array}$ & $\begin{array}{r}461 \cdot 6 \\
89 \cdot 7 \\
19 \cdot 5 \\
2 \cdot 1\end{array}$ & $\begin{array}{c}2682^{* * *} \\
500^{* * *} \\
24 \\
8 * *\end{array}$ & $\begin{array}{c}2638 * * * \\
616 * * * \\
86 * * * \\
-2\end{array}$ & $\begin{array}{l}\text { I } 282 * \\
364 * * * \\
28 \\
-6 * *\end{array}$ \\
\hline \multicolumn{9}{|c|}{ Total activity (units) in large intestine } \\
\hline $\begin{array}{l}\text { Maltase } \\
\text { Sucrase } \\
\text { Palatinase } \\
\text { Lactase }\end{array}$ & $\begin{array}{r}443 \\
74 \\
16 \\
5\end{array}$ & $\begin{array}{r}1069 \\
205 \\
56 \\
7\end{array}$ & $\begin{array}{r}891 \\
221 \\
55 \\
132\end{array}$ & $\begin{array}{r}1360 \\
408 \\
100 \\
40\end{array}$ & $\begin{array}{l}\text { I } 69 \cdot 7 \\
53 \cdot 1 \\
10.8 \\
22 \cdot 0(a)\end{array}$ & $\begin{array}{c}548 * * \\
-159 * \\
-42 * * \\
45\end{array}$ & $\begin{array}{l}-370 \\
-175 * * \\
-42 * * \\
-80 *\end{array}$ & $\begin{array}{r}-78 \\
28 \\
2 \\
-47^{*}\end{array}$ \\
\hline
\end{tabular}

(a) For lactase the SE of group means are heterogeneous. The SE of each conventional group is $\pm 3 I \cdot 0$, the SE of the germ-free group on the lactose diet is $\pm I \cdot 9$ and the SE of the germ-free group on the starch diet is $\pm r \cdot 3$. The value of 22.0 quoted in the table is a pooled value applicable to main effects and the interaction.

Levels of significance: * $P<0.05, * * P<0.01$, *** $P<0.001$.

$\dagger$ The SE of a group mean, $s$, refers to a group of fifteen birds. The SE of the mean of group $(A)$ with seven birds is $s \sqrt{ }\left(1_{5} / 7\right)$. The SE of a main effect or of the interaction is $s \sqrt{ }(9 / 7)$.

\section{DISCUSSION}

Results of any investigation of enzyme activities in the gut of germ-free and conventional chickens are likely to be confounded by the differences in morphology of the alimentary tract known to exist between birds in the two environments. The weight per unit length of small intestine of the germ-free chick is usually considerably less than that of its conventional counterpart, a difference that is largely due to the greater amount of connective tissue in the gut wall of the conventional bird (Gordon \& Brückner-Kardoss, 196r). The intestinal disaccharidases are located in the brush border but, since clean separation of the mucosa from the rest of the tissue is not feasible in the chick intestine, our determinations were made on homogenates of whole intestinal wall. If, as is customary, the results had been expressed per $\mathrm{g}$ tissue or per mg protein, comparisons between values for germ-free and conventional birds would have been biased by the difference in gut thickness in the two environments, the thicker wall of the conventional chick inevitably leading to a lower value. Thus the total amount of 
enzyme in the whole intestine was considered to be the most valid method of presenting the results.

Results of an initial exploratory test using a purified diet confirmed, in both environments, the earlier findings of Siddons (1969) regarding the amounts and distribution of disaccharidase activity throughout the intestinal tract of conventional chicks. In the small intestine maltase was present in greatest abundance, with about one-fifth as much sucrase and considerably less palatinase; lactase was virtually absent. About $97 \%$ or more of the activity was present in the wall. There were no differences between birds in the two environments. The large intestine contained much smaller amounts of maltase, sucrase and palatinase which, being mostly in the contents, were probably carried with the digesta from the small intestine. In the conventional birds the large intestinal contents had appreciable lactase activity, presumably of bacterial origin since none occurred in the corresponding germ-free samples. In this experiment there was significantly less maltase in the conventional birds, possibly indicating some destruction by microbial action during passage through the tract. However, this finding was not confirmed in subsequent experiments. Some differences were noted in the enzyme activities of fasted and fed birds. In general, the fasted birds showed lower enzyme activities in the small intestine, presumably owing to lack of stimulus during the time that food was withheld, and higher activities in the large intestine, perhaps because the rate of passage of digesta would be more rapid after a period of fast. In all subsequent experiments samples were taken after a $\mathrm{I} 6 \mathrm{~h}$ fast and determinations were made on the combined wall and contents.

In a second experiment, using the practical chick mash, the same order of enzyme activities throughout the intestinal tract was observed but on this occasion there were significantly greater amounts of maltase, sucrase and palatinase in the small intestine of germ-free compared with conventional chicks. In view of the different findings in this and the previous experiment with the purified diet, a direct comparison was made in both environments between disaccharidase activities in birds given the purified diet or the chick mash. There was again a greater amount of maltase, sucrase and palatinase in the small intestine of germ-free birds given the mash, but no such difference between germ-free and conventional chicks given the purified diet. On the mash, the germ-free birds grew significantly more than their corresponding conventional controls, whereas no difference in weight was observed on the purified diet. It is reasonable to suppose that the heavier birds would have had a correspondingly larger gut with a greater surface area and therefore more numerous mucosal cells. When, as Fig. I shows, the results in Table 4 were recalculated in terms of body-weight, differences between disaccharidase activity in germ-free and conventional birds disappeared. Thus it appears that the lower levels of activity in the conventional compared with the germ-free birds given mash was the indirect result of a lower bodyweight and consequently smaller gut area, and that the concentration of enzyme per cell was probably much the same in both environments. Abrams, Bauer \& Sprinz (1963) showed that the rate of turn-over of mucosal cells in the rat is accelerated by the presence of micro-organisms. Reddy et al. (1968) interpreted the higher disaccharidase activity that they found in the intestine of germ-free rats to be a reflection of the 
greater maturity and thus, they presumed, higher enzyme content, of the mucosal cells. In earlier work neither Larner \& Gillespie (I957) nor Dahlquist, Bull \& Gustafsson (1965) had been able to demonstrate any differences in the levels of disaccharidase activities between germ-free and conventional rats. Our results suggest that, in the chick, there is no difference other than can be accounted for by an indirect effect of a higher body-weight of the germ-free birds.

In the comparison between mash and purified diets there was a general tendency to higher values on the mash in both environments, even though the birds weighed less. It is well known that a fibrous, bulky diet leads to an increase in gut volume. On gross examination, the intestines from the mash-fed birds were larger in diameter than those from birds on the purified diet, hence a greater surface area seems the most probable explanation for the higher enzyme content of the intestines of the mash-fed groups. An attempt was made to simulate the more bulky nature of the mash by replacing part of the carbohydrate in the purified diet with powdered wheat straw. For comparison, a diet with glucose as the source of carbohydrate, with and without wheat straw, was also included. As Table 5 shows, there was little effect of inclusions of fibre either on body-weight or on small-intestine weight, hence this investigation provided no further evidence concerning the relation between gut size and disaccharidase content. Contrary to expectation, the small intestines of the birds given diets with added fibre had the lowest enzyme activities, possibly because the fibre was included at the expense of starch, thus creating a reduced demand for carbohydrate digestion.

In all the experiments reported, little or no lactase was detected in the gut of germfree birds, but appreciable amounts were present in the contents of the large intestine of conventional chicks. There was more lactase in the conventional birds given the mash than in those given the purified diet. Since the mash contained some lactose contributed by the skim-milk powder, it seemed likely that the establishment of lactaseproducing organisms was encouraged by a lactose substrate. This suggestion was strengthened when enzyme activity was compared in birds given the purified diet containing either starch or lactose as the sole carbohydrate source. As expected, negligible quantities of lactase were detected in the small intestine of all groups and in the large intestine of the germ-free birds. Lactase was present in the large intestines of both groups of conventional birds, and the amount was higher in birds on the lactose diet. Performance of all the birds given lactose was poor but, since the survival rate of the conventional group was considerably better than that of their germ-free counterparts, it appears that at least some of the products of lactase digestion in the large intestine were available to the host.

From these results we conclude that micro-organisms in the alimentary tract have no direct effect on disaccharidase production in the small intestine in the chick. 'The greater activities of maltase, sucrase and palatinase in germ-free compared with conventional birds given the mash diet were probably the indirect effect of the larger body-weights achieved in the germ-free environment. Some microbial destruction of disaccharidases may occur during passage through the large intestine. Lactase is not directly produced by the bird but arises from microbial action in the large intestine. The amount is higher if the diet contains lactose, and some of the end-products of 
lactase digestion are utilized by the bird, presumably by direct absorption from the caecums or colon or both.

We are grateful to our colleagues Dr D. J. Jayne-Williams for sterility checks on the germ-free isolators, $\mathrm{Mr} \mathrm{J}$. P. Fordham for carc and management of the experimental birds, Mr R. J. Merry for technical assistance and Miss R. J. Warren for statistical analysis of the results.

\section{REFEREN CES}

Abrams, G. D., Bauer, H. \& Sprinz, H. (1963). Lab. Invest. 12, 355.

Dahlqvist, A., Bull, B. \& Gustafsson, B. E. (I965). Archs Biochem. Biophys. rog, 150.

Fuller, R. (1968), In The Germ-free Animal in Research Ch. 2. [M. E. Coates, editor]. London and New York: Academic Press.

Gordon, H. A. \& Brückner-Kardoss, E. (1961). Acta Anat. 44, 2 10.

Harrison, G. F. (r969). Lab. Anim. 3, 5 I.

Larner, J. \& Gillespie, R. E. (I957). F. biol. Chem. 225, 279.

Reddy, B. S., Pleasants, J. R. \& Wostmann, B. S. (1968). \%. Nutr. 95, 4r 3.

Reddy, B. S. \& Wostmann, B. S. (I966). Archs Biochem. Biophys. xr3, 6og.

Siddons, R. C. (1969). Biochem. F. 112, $5 \mathrm{I}$.

Siddons, R. C. (1970). Biochem. 7 . 116, 7. 